\title{
WOMEN IN INFORMATION TECHNOLOGY EVENT: WHICH IS THE RESEARCH CONTEXT IN BRAZIL?
}

\author{
Pricila Castelini ${ }^{1}$ and Marília Abrahão Amaral $^{2}$ \\ Postgraduate Program in Technology and Society (STS) - Federal University of Technology \\ Paraná (UTFPR) - Curitiba, Brazil
}

\begin{abstract}
Women participation in computer science and related areas in Brazil is fewer than men, considering quantitative researches on both labor market and academic space. Brazilian Society of Computing supports an initiative to discuss the disparities in this issue in Brazil: Women in Information Technology - WIT. We analyze 81 short papers published on $10^{\text {th }}, 11^{\text {th }}$, and $12 t^{\text {th }}$ editions of the event to highlight information on interests, practices, and origins of these papers. We base our analysis on Science, Technology, and Society (STS) and Feminist studies and we point out to plural and inclusive computing that open participation of all people in all spheres of society considering the social, cultural and historical aspects of society in the $21^{\text {st }}$ century.
\end{abstract}

\section{KEYWORDS}

Women, Computing, STS Studies, Feminist Studies

\section{THE CONTEXT}

In a Brazilian context, practices on computing are culturally and socially naturalized as a male-dominant world. Monard and Fortes (2013) point out that women are not looking for undergraduate courses in computing. They indicate that computation undergraduate courses in Brazil do not follow the demand for gender equality. Open data from the National Institute for Educational Studies and Research Anísio Teixeira (INEP, 2018) show that women participation in computing in Brazil it is only $20,1 \%$.

Meaning, it is assumed that men are those in charge of the production of technological artifacts for society. This trend has historical roots that can be traced to World War II. According to Abbate (2012) between 1940 and 1950 women worked in computing more than men did, but this initial success has historically declined. Hence, women "do not participate from design and development of the products" (WAJCMAN, 2006, p. 44). According to Gomes (2006), "our great challenge is to develop an ethical posture of not prioritizing differences and understand that no human and social group is better or worse than another. We're different" (GOMES, 2006, p. 22).

Women are the majority in university in Brazil, mostly enrolled in courses for teaching or personal caring, e.g., nursing and teacher (MONARD; FORTES, 2013). Traditional values, such as science purity and universality, are coincident with men's stereotypes. Hence, it constitutes another barrier to women entering the field. Women are not looking for these courses, with numbers showing that computing area does not follow the demand for gender equality (Abbate, 2012; Margolis, Fisher, 2002).

Women in Information Technology (WIT) is a venue to discuss and to improve the understanding of these issues. It aims to advance women participation in technology bringing together researchers and activists. Since 2016, WIT has included short papers in its call for work in progress. Is important to recognize that discussions, events, and programs in technology/computing area versing on women participation have begun with counterculture, feminism movements from 1960 and in academic research years later. Clearly, an event does not mean that the current barriers to women in tech are going to diminish, but it is an important space for the community concerned with more democracy on computation. Considering the feminism

\footnotetext{
pricilacas@hotmail.com

mariliaa@utfpr.edu.br
} 
movements from the early 1960 and academic researches mentioned, we analyze the 81 published short papers from WIT 2016, 2017 and 2018. The second section presents the context of the event and 81 published short papers and the categories for analysis, the third section presents the categories analysis, and the fourth section presents final remarks.

\section{WOMEN IN INFORMATION TECHNOLOGY (WIT) - 2016-2018}

Women in Information Technology (WIT) is an initiative supported by the Brazilian Computing Society (SBC) to discuss gender in technology. Therefore, WIT focuses on women access to information technology, from the point of view of the labor market and Academia. Submissions are invited to discuss success histories; incentive policies; engagement of young people especially women associate with technological careers (CSBC, 2017). In 2016, 25 short papers were published, in 2017, 28 short papers, and in 2018, 28 short papers were published. Among the short papers submitted in the three editions of the event, some of them were written together by researchers from different regions of Brazil. In this case, we consider them separately.

As region distribution, WIT 2016 has: North of the country has published 2 short papers; Northeast, 6 short papers; Midwest, 5 short papers Southeast, 1 short paper; and South, 12 short papers have been published. WIT 2017 presents the following numbers: North, 4 short papers; Northeast, 7 short papers; Midwest, 6 short papers; Southeast, 3 short papers; and South, 8 short papers. In WIT 2018 we have found: North, 1 short paper Northeast, 11 short papers; Midwest, 7 short papers; Southeast, 7 short papers; and South, 3 short papers. Table 1 shows recurring categories lined up as similar categories and the second part presents the country region and the quantities of published short papers.

Table 1. Trends in topics of three event editions

\begin{tabular}{|c|c|c|c|c|c|}
\hline \multicolumn{2}{|l|}{ WIT 2016} & \multicolumn{2}{|c|}{ WIT 2017} & \multicolumn{2}{|c|}{ WIT 2018} \\
\hline Recurring categories & $\begin{array}{l}\text { Region and } \\
\text { quantities }\end{array}$ & Recurring categories & $\begin{array}{l}\text { Region and } \\
\text { quantities }\end{array}$ & $\begin{array}{l}\text { Recurring } \\
\text { categories }\end{array}$ & $\begin{array}{c}\text { Region and } \\
\text { quantities }\end{array}$ \\
\hline $\begin{array}{l}\text { Workshops, activities } \\
\text { with high school students }\end{array}$ & $\begin{array}{l}9 \text { South } \\
3 \text { Midwest } \\
1 \text { Northeast }\end{array}$ & $\begin{array}{l}\text { Workshops or activities } \\
\text { with elementary and } \\
\text { high school students }\end{array}$ & $\begin{array}{l}4 \text { South } \\
1 \text { Southeast } \\
4 \text { Midwest } \\
3 \text { North } \\
2 \text { Northeast }\end{array}$ & $\begin{array}{l}\text { Workshops or } \\
\text { activities with } \\
\text { students }\end{array}$ & $\begin{array}{l}1 \text { Southeast } \\
2 \text { Midwest } \\
1 \text { North }\end{array}$ \\
\hline $\begin{array}{l}\text { Presented incentive } \\
\text { groups for women } \\
\text { participation in the area }\end{array}$ & $\begin{array}{l}1 \text { Northeast } \\
\text { \& Midwest } \\
1 \text { South } \\
1 \text { North }\end{array}$ & $\begin{array}{l}\text { Analyze the } \\
\text { participation of female } \\
\text { students in educational } \\
\text { institutions }\end{array}$ & $\begin{array}{l}1 \text { Midwest \& } \\
\text { South } \\
1 \text { Northeast } \\
2 \text { Southeast }\end{array}$ & $\begin{array}{l}\text { Incentive activity } \\
\text { with students }\end{array}$ & $\begin{array}{l}7 \text { Northeast } \\
2 \text { Southeast }\end{array}$ \\
\hline $\begin{array}{l}\text { Questionnaire with } \\
\text { female audience }\end{array}$ & 1 Northeast & $\begin{array}{l}\text { Presented results of } \\
\text { questionnaires applied } \\
\text { with recent grads in } \\
\text { computer science }\end{array}$ & $\begin{array}{l}1 \text { South } \\
1 \text { North }\end{array}$ & $\begin{array}{l}\text { Presented } \\
\text { questionnaire } \\
\text { applied with } \\
\text { students }\end{array}$ & 1 Southeast \\
\hline $\begin{array}{l}\text { Presented case study and } \\
\text { examples of the reasons } \\
\text { for women follow a } \\
\text { computing career }\end{array}$ & 1 South & Student profile analysis & $\begin{array}{l}2 \text { Northeast } \\
1 \text { Midwest }\end{array}$ & $\begin{array}{l}\text { Student profile } \\
\text { analysis and case } \\
\text { study }\end{array}$ & $\begin{array}{l}1 \text { South } \\
2 \text { Northeast } \\
2 \text { Midwest }\end{array}$ \\
\hline $\begin{array}{l}\text { Teachers and students of } \\
\text { higher education }\end{array}$ & $\begin{array}{l}1 \text { Southeast } \\
3 \text { Northeast }\end{array}$ & $\begin{array}{l}\text { Trajectories of black } \\
\text { women teachers in } \\
\text { computing }\end{array}$ & 1 Northeast & $\begin{array}{l}\text { Literature review } \\
\text { that discusses } \\
\text { black women in } \\
\text { computing }\end{array}$ & 1 Midwest \\
\hline
\end{tabular}

Table 2 shows unique categories and the second part presents the country region and the quantities of published short papers. 
Table 2. Specific topics of three event edition

\begin{tabular}{|c|c|c|}
\hline \multicolumn{2}{|r|}{ Categories } & Region and quantities \\
\hline 016 & Games and apps & $\begin{array}{l}1 \text { Midwest } \\
1 \text { South } \\
1 \text { North }\end{array}$ \\
\hline \multirow{4}{*}{2017} & Examines gender violence in the computing area & 1 South \\
\hline & Analyses the speech in programs that encourage women participation in computing & 1 South \\
\hline & $\begin{array}{l}\text { Presented research that discusses the regulatory and exclusionary constructions in } \\
\text { computing }\end{array}$ & 1 South \\
\hline & Presented a mapping of harassment in public transport & 1 Northeast \\
\hline \multirow{8}{*}{2018} & Research on women barriers to access computing area & 1 Northeast \\
\hline & Women participation in game jams & 1 Northeast \\
\hline & Research with students about professional choice & 1 South \\
\hline & Research with students and undergraduate & 1 Midwest \& Southeast \\
\hline & A platform that helps to evaluate work conditions for women & 1 Southeast \\
\hline & Presents a bibliographic analysis on women participation in game development process & 1 South \\
\hline & Research about women presence in electronic game development in Brazil & 1 Midwest \\
\hline & Qualitative study with men and women that work in a technology company & 1 Southeast \\
\hline
\end{tabular}

\section{WIT 2016, 2017 AND 2018 CATEGORIES OF ANALYSIS}

We do our analysis on research categories: "quantitative data", "recurring topics", and "region". Based on STS and feminist studies, we identify disputes between ideas forged on technological determinism and neutrality of science, and views considering that the social aspects have a direct influence on the scientific-technological transformations. Also, we identify concerns about the environmental and social consequences on the people and the world.

In STS and feminist studies [WAJCMAN, 2006; HARAWAY, 1995], authors indicate disproportionality between men and women and points out the importance not only approximate women to the area, indeed to discuss the social and cultural values that move away from women to study and work in the computing area. This context is crucial in gender relations in Academia and the labor market because most of the short papers we analyze present misogynistic perceptions, repellent and aggressive to women presence in academic space and the labor market in computing.

In the category "recurring topics", authors showcase workshops and activities with elementary and high school students, composing 31 short papers in all three event editions. In the second place is the description of incentive groups for women participation in the area: 16 short papers. Reasons for women follow a computing career and students profile are present in 8 documents. Researches about student profile analysis and case study have 5 total. The last recurring category identified was about teachers of higher education and black women teachers in the area, has 6 short papers submitted.

In the category "quantitative data", we observe WIT receives researchers doing work with students in high and elementary school. The category "region and quantities" involves people participation from the whole country; in this category, we can identify that in Northeast and South had more submitted short papers the context in social, economic and cultural aspects may be an implication for future work. Most of the short papers analyzed reinforce the differences between men and women with exclusive groups. We point out the importance of closer participation of people with disabilities, race, and ethnicity, cultural and situated aspects [HARAWAY, 1995], it also has a reflective and activist on multiple identities and intersections in society that reflects on technology, on computing, on design, in everyday life and also in the labor market where there are several prejudices and gender discrimination. 


\section{CONCLUSION}

In this short analysis of three event editions, we argue that woman participation in computing is very important for society, considering the cultural and historical conditions that invisibilized and silenced women to participate in decision-making and daily life in human history. We present this analysis based on plural and inclusive for computing. Based on STS and feminist studies, the authors indicate that it is not enough to approximate women to study and work in computing. It is also a reflection of daily actions, whereas society, culture, and history. Although there are many activities in the country to approach women in computing, there is still lack of reflections, activism, and discussion about an inclusive and not exclusive computing area, to bring all people and not to create exclusive groups.

Besides, as a future implication of this research is to discuss the social, cultural and economic aspects that are in the margins of society considering the multiple identities and intersections that need to follow this conception of society (and computing) free, unattended and without prejudices and judging. We observed that there is a plurality of approaches that are different for each person and each context and is even more visible by the support of cultural and historical discourse. We point out the importance to consider a wide, not restricted, and open participation of all people in all spheres of society, even in computing.

\section{ACKNOWLEDGMENT}

We thank the Postgraduate Program in Technology and Society (PPGTE) of the Federal University of Technology - Paraná (UTFPR) for the support in developing this research. This study was financed in part by the Coordenação de Aperfeiçoamento de Pessoal de Nível Superior (CAPES) - Finance Code 001.

\section{REFERENCES}

Abbate, J. Recoding gender: women's changing participation in computing. [S.1]: MIT Press, 2012.

Gomes, N. L. Culture diversitym curriculum and race issue. Challenges for educational practise. In: ABRAMOWICZ, Anete, BARBOSA, Maria de Assunção e SILVÉRIO, Valter Roberto (Orgs). Practical education difference. Campinas, Armazém do Ipê, pp. 21-40.

Haraway, D. 1998. Situated knowledges: the science question in feminism and the privilege of partial perspective. Vol. 14, No. 3. Feminist Studies, Inc. pp. 575-599.

INEP. Relatório Censo da Educação Superior 2018. Instituto Nacional de Estudos e Pesquisas Educacionais Anísio Teixeira. Available in: http://www.inep.gov.br/ Accessed in: 01 abr., 2019.

Margolis, J; Fisher, A. Unlocking the clubhouse: Women in computing. 2002. ed [S.1: s.n.], 2002

Monard, M. C; Fortes, R. "A View of women participation in Computer Science courses in Brazil." V Congresso de la Mujer Latinoamericana em La Computacion - LAWCC 2013, p. 6 - 12, 2013. Available in: <http://sites.labic.icmc.usp.br/pub/mcmonard/MonardLAWCC2013.pdf.pdf >. Accessed in: Apr 22, 2019.

Wajcman, J. 2006. Technofeminism. Ediciones Cátedra. Madrid. 